\title{
The contribution of engineering surveys by means of GPS to the determination of crustal movements in Istanbul
}

\author{
M. Özyaşar and M. T. Özlüdemir \\ Istanbul Technical University, Dept. of Geomatics Engineering, IGS ISTA Satellite Observation and Processing Laboratory, \\ 34469 Maslak, Istanbul, Turkey
}

Received: 23 March 2011 - Revised: 19 May 2011 - Accepted: 30 May 2011 - Published: 17 June 2011

\begin{abstract}
Global Navigation Satellite Systems (GNSS) are space based positioning techniques and widely used in geodetic applications. Geodetic networking accomplished by engineering surveys constitutes one of these tasks. Geodetic networks are used as the base of all kinds of geodetic implementations, Co from the cadastral plans to the relevant surveying processes during the realization of engineering applications. Geodetic networks consist of control points positioned in a defined reference frame. In fact, such positional information could be useful for other studies as well. One of such fields is geodynamic studies that use the changes of positions of control stations within a network in a certain time period to understand the characteristics of tectonic movements. In Turkey, which is located in tectonically active zones and struck by major earthquakes quite frequently, the positional information obtained in engineering surveys could be very useful for earthquake related studies. For this purpose, a GPS (Global Positioning System) network of 650 stations distributed over Istanbul (Istanbul GPS Triangulation Network; abbreviated IGNA) covering the northern part of the North Anatolian Fault Zone (NAFZ) was established in 1997 and measured in 1999. From 1998 to 2004, the IGNA network was extended to 1888 stations covering an area of about $6000 \mathrm{~km}^{2}$, the whole administration area of Istanbul. All 1888 stations within the IGNA network were remeasured in 2005. In these two campaigns there existed 452 common points, and between these two campaigns two major earthquakes took place, on 17 August and 12 November 1999 with a Richter scale magnitude of 7.4 and 7.2, respectively. Several studies conducted for estimating the horizontal and vertical displacements as a result of these earthquakes on NAFZ are discussed in this paper. In geodynamic projects carried out before the earthquakes in 1999, an annual average ve-
\end{abstract}

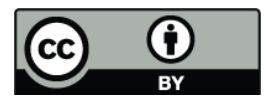

Correspondence to: M. T. Özlüdemir (tozlu@itu.edu.tr) locity of $2-2.5 \mathrm{~cm}$ for the stations along the NAFZ were estimated. Studies carried out using GPS observations in the same area after these earthquakes indicated that point displacements vary depending on their distance to the epicentres of the earthquakes. But the directions of point displacements are similar. The results obtained through the analysis of the IGNA network also show that there is a common trend in the directions of point displacements in the study area. In this paper, the past studies about the tectonics of Marmara region are summarised and the results of the displacement analysis on the IGNA network are discussed.

\section{Tectonical background}

Anatolia is located on the Alps-Himalayas orogeny, one of the most active seismic belts in the world. The mentioned seismic belt starts at the Azores and stretches as far as to Indonesia in the Far East. In general, it is an active belt that is affected by the relative movements of the plates of Eurasia, Africa, and India-Australia (McKenzie, 1972). Turkey and its surroundings constitute the most kinetic section of the Mediterranean part of this active seismic belt, as well as portraying its general characteristics. Anatolia also presents a number of specific geological properties. The geology of Turkey, located between the plates of Eurasia in the north and Africa-Arabia in the south, has developed according to the constant movements of these two plates and the geotectonic evolution of the old and new Tethys Ocean located between these plates. The Arabian plate collides with Eurasia along the Bitlis thrust zone. As a result of the Arabian plate moving north and hitting Eurasia, Eastern Anatolia became stuck in the direction of northwards-southwards and a new tectonic era started over the whole Anatolian plate.

Today, the young and active tectonic movements observed in Anatolia are the product of this collision mechanism, whose fault zones and earthquake activities started 15 million

Published by Copernicus Publications on behalf of the European Geosciences Union. 


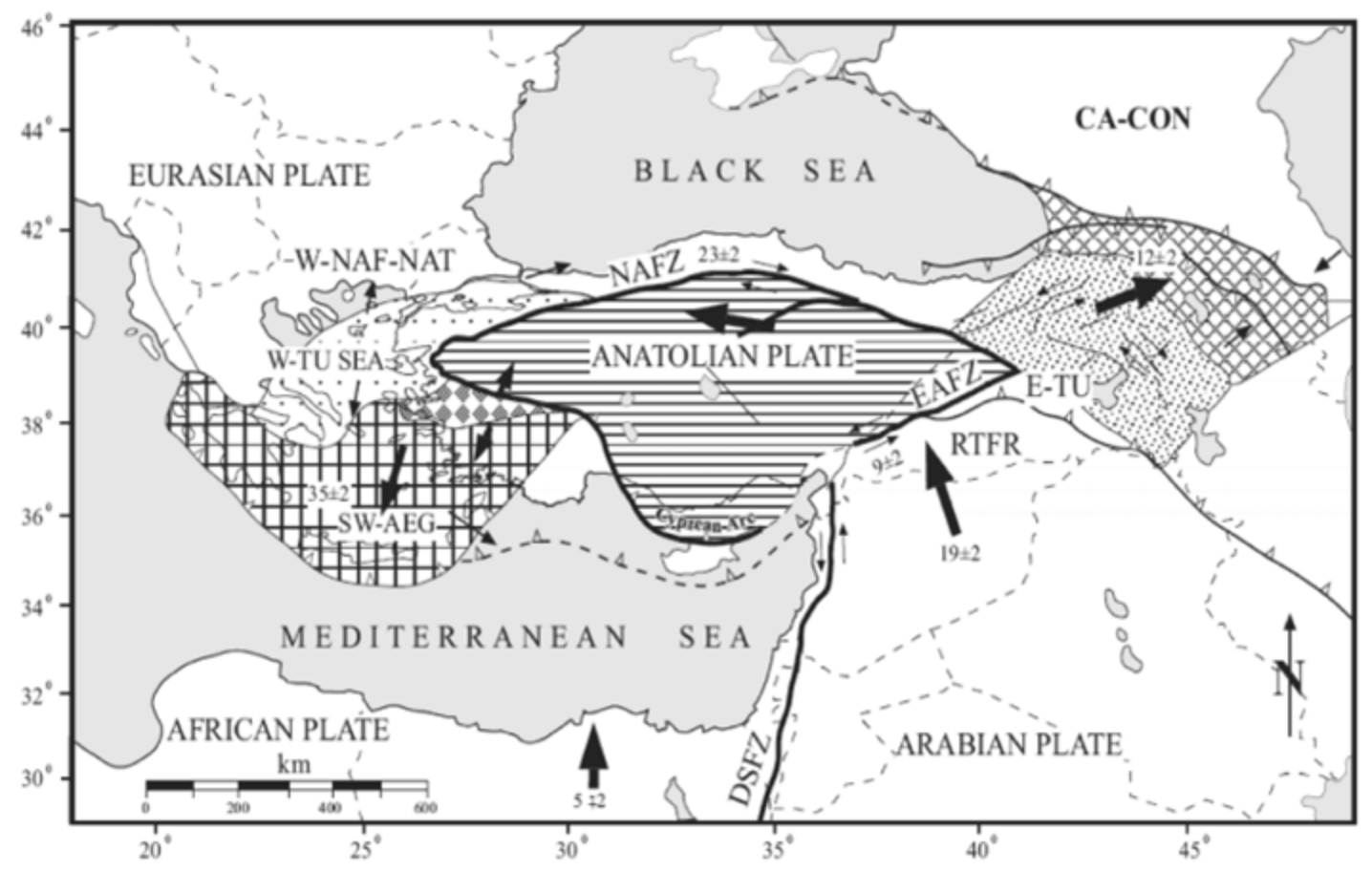

Fig. 1. Tectonic map of Turkey and the surrounding areas. Hatched areas show the coherent motion of specific zones of deformation. Heavy arrows indicate the generalised regional motions in $\mathrm{mm} \mathrm{yr}^{-1}$ (McClusky et al., 2000).

yr ago and continue still today (Fig. 1). The northern part of the Arabian plate and the north-eastern part of the African plate move relative to the Eurasian plate northwards. In the Bitlis-Zagros shock zone, the Arabian and African plates collide with the southern part of the Eurasian plate, squeezing East Anatolia. Consequently, the Anatolian plate moves relative to the Eurasian plate westwards and relative to the African plate in west-southwestern direction. The stress caused by this mechanism gave rise to the formation of fault zones in North Anatolia and East Anatolia, which increased the magnitude of westward movement of the Anatolian plate (Şengör, 1979).

The NAFZ is a seismically active right lateral fault zone with a length of about $1200 \mathrm{~km}$ from Karliova in the east to the Gulf of Saros in the west. The current state of the NAFZ is a result of major earthquakes that have occurred over the past centuries, starting from the eastern part of the NAFZ towards/to the western part. The earthquakes with large magnitudes caused surface faulting and broke an $800 \mathrm{~km}$ section of the fault. As a result of geological investigations, horizontal and vertical displacements varying between $1.5 \mathrm{~m}-4.5 \mathrm{~m}$ and $40 \mathrm{~cm}-100 \mathrm{~cm}$ formed on the cracks that were detected. A nearly $90 \mathrm{~cm}$ right lateral movement occurred between the two blocks of the fault (Ketin, 1969). Between 1900 and 1998, 34 devastating earthquakes recorded along the NAFZ with a magnitude of more than 5.5 of Richter scale ( 9 of those earthquakes had a magnitude larger than 6.5 of Richter scale). Additionally, over a period of three months, includ- ing the dates 17 August 1999 (Izmit) and 12 November 1999 (Düzce), two major earthquakes occurred in the east of the Marmara Region, which is a section of the NAFZ. Huge losses of lives and property were experienced in the region due to these earthquakes (Barka, 1999). Figure 2 shows the major earthquakes that took place along the NAFZ including the latest Izmit and Düzce earthquakes.

Numerous scientific studies have been carried out dealing with the tectonical characteristics of the NAFZ before and after these two earthquakes occurred in the east of Marmara region in 1999. Some of these studies included various geological and geophysical measurements for the shelf, slope, and deep plane of the sea, collected samples, filmed underwater videos of the active faultline, and used high technology instruments and devices. The main objectives of the studies focus on the structural evolution, the seismicity, and the depositional processes and bathymetry of the Marmara Sea. The objective of geodetic studies, on the other hand, is to determine the location, direction, and magnitude of displacements caused during and after an earthquake, or because of small crustal movements causing earthquakes and crustal stress. Local control networks or national geodetic networks were used to achieve this objective. As an example to such studies, McClusky et al. (2000) summarize the characteristic properties of plate movements in the area of eastern Mediterranean on the basis of GPS observations conducted from 1988 to 1997 with following the statements: 


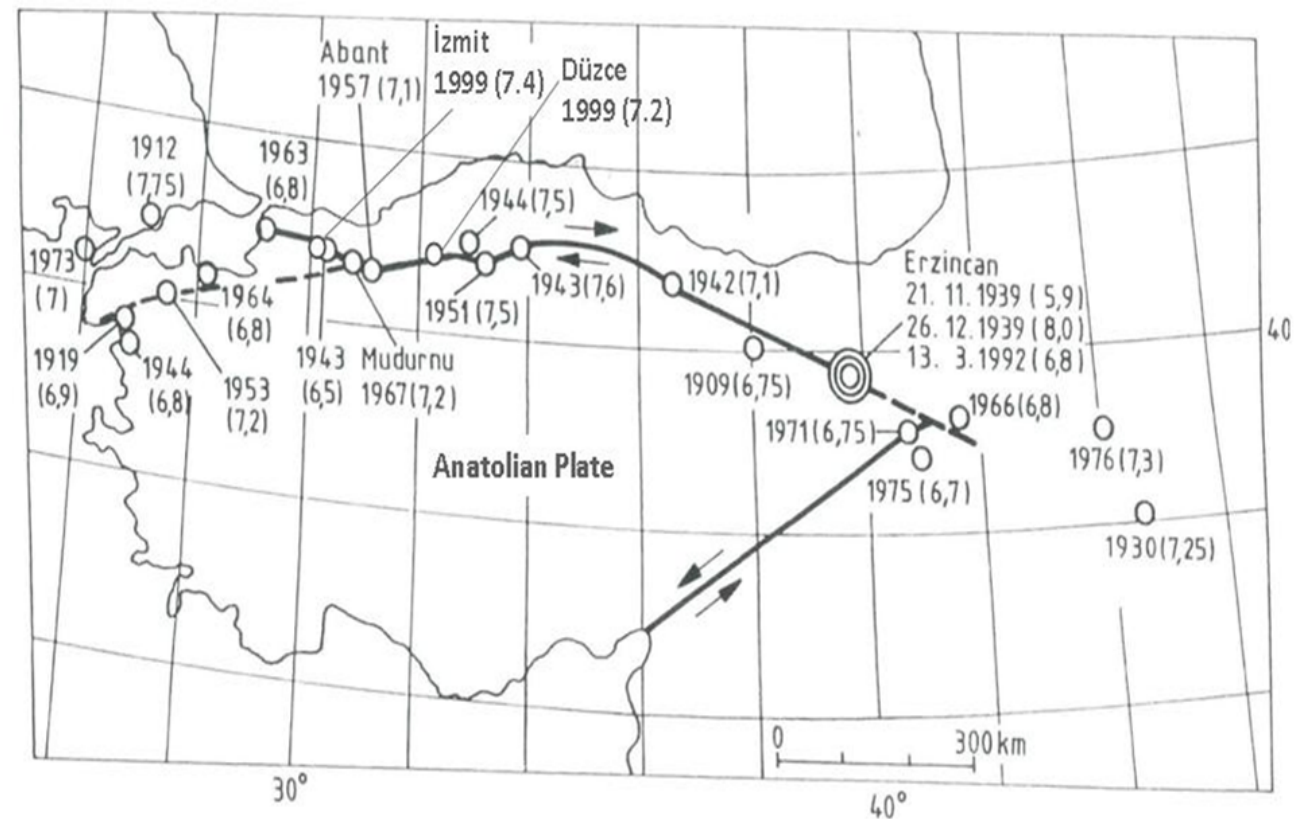

Fig. 2. The dates and magnitudes (in brackets) of major earthquakes along the NAFZ (modified from Altiner, 1996).

- As a result of the rapid north-northwest movement of the Arabian plate relative to the Eurasian plate, the Eastern Anatolia region is squeezed and the Anatolian plate turns anticlockwise, towards the west, at a speed of 20$25 \mathrm{~mm} \mathrm{yr}^{-1}$.

- The African plate slides under the Anatolian plate with a westward movement at a speed of $5-10 \mathrm{~mm} \mathrm{yr}^{-1}$.

- The Aegean plate extends in the direction of northsouth.

\section{Tectonical impact of the two large 1999 earthquakes on the study area}

The Marmara region is the area delimited by approximately east longitudes of $26^{\circ}$ to $31^{\circ}$ and north latitudes of $40^{\circ}$ to $41^{\circ} .30^{\prime}$. It is shaped by a number of structural highlands, basins and blocks, and fault-controlled basins to sea ways. Seismicity of the Marmara region is relatively very high, as indicated by both the historical and recent (instrumental period) devastative earthquakes. The Marmara region has experienced 18 historical earthquakes with intensities of MM (Modified Mercalli Scale) between IX and X in the period of AD 29 and AD 1894, and 13 recent devastating earthquakes with magnitudes of 6.1 to 7.4 on the Richter scale in the period of 1912 to 1999 occurred in the Marmara region. These statistical values correspond to the occurrence of an approximately every $100 \mathrm{yr}$ historical and every $7 \mathrm{yr}$ recent destructive earthquakes in the Marmara region. These statistical data point out that the Marmara region experiences a historical devastating earthquake every one hundred years. This high rate of seismicity has a critical importance for the earthquake hazard in the Marmara region, because approximately $25 \%$ of Turkey's population and most of its industrial centres are included in this region (Koçyiğit, 2006).

The major 1999 Izmit earthquake occurred at 03:02 EEST on 17 August, with a magnitude of 7.4 on the Richter scale, whose epicentre was around the district of Gölcuik located $12 \mathrm{~km}$ southeast of the centre of Izmit, an industrial town in the southeast of the Marmara Region. During this earthquake, a rupture exceeding $120 \mathrm{~km}$ formed, stretching from the southwest of Düzce to the northwest of Yalova, located on the Marmara Sea. The largest damage occurred in the cities of Kocaeli and Sakarya during this earthquake. The observation is that the earthquake developed as a right lateral strike slip fault. This observation complies with the general characteristics of the NAFZ (Cerit et al., 1999).

This earthquake that lasted approximately $45 \mathrm{~s}$ caused a huge loss of lives and property in the Marmara region that had (and has of this writing) a population over 20 million. As previously emphasised, the earthquake in Izmit created a nearly $120 \mathrm{~km}$ rupture causing up to $5.7 \mathrm{~m}$ displacements in opposite directions of the fault line. The Gulf of Izmit is on the north branch of the NAFZ. The Gulf of Izmit has one fault line extending to the Gulf of Saros, setting an example for the development of parallel secondary fault lines. In particular, the fault lines that establish the Gulf of Izmit are important elements with regard to the definition of the sequence of the structures observed in the Marmara Sea (Alpar and Yaltırak, 1999). 
In their study conducted using GPS data collected on the stations distributed over Marmara region before and after the earthquake in Izmit on the 17 August 1999, Reilinger et al. (2000) calculated the horizontal and vertical displacements relative to the Eurasian plate with a confidence level of 0.95 using common points within the network, to understand the tectonical impact of earthquakes on the area of the earthquake epicentre and surrounding domain. The average right lateral strike slip along the fault plane of the earthquake in Izmit, together with the inversion analysis of the lateral strike slip measurements in an elastic half-space, was $2.86 \mathrm{~m}$. The fault plane was accepted as input in the model created and a dislocation model was established in an elastic halfspace. The total strike slip movements that occurred during the earthquakes in Izmit and Düzce at the first and second degree lateral control points within the region were calculated. The horizontal control point nearest to the surface crack was approximately $10 \mathrm{~km}$ away, while a maximum displacement between 1.5 and $2 \mathrm{~m}$ was observed at these points. It was observed that the displacement between the first and second degree horizontal control points, eastward north of the surface crack, and westward south of the surface crack, moved 3-4 m from each other. The 1999 Izmit earthquake exhibits a maximum of surface displacements $5 \mathrm{~m}$ at the nearest point to the surface crack, and decreased as the distance from the surface crack increased. Displacements were eastward north of the surface crack, and westward south of the surface crack. Deformation continued in the structure and along the fault line for nearly three months after the earthquake, the aftershock period. It is thought that horizontal control points move maximally up to $10 \mathrm{~cm}$ from each other due to displacements after the earthquake. The maximum displacements caused by the 1999 earthquake in Izmit appeared in Gölcük, and west and east Sapanca. A $5.7 \mathrm{~m}$ displacement was determined west of the earthquake epicentre, and a $4.7 \mathrm{~m}$ displacement was determined east of the epicentre of the earthquake (Reilinger et al., 2000). In their study, Kutoğlu et al. (2011) determined horizontal displacements of up to $2.15 \mathrm{~m}$ in the eastern part of Sapanca.

In another study, Ayhan et al. (2002) analysed GPS data collected in the western section of NAFZ covering the Marmara region. The measurements had been conducted in 23 campaigns in cooperation with the Federal Agency for Cartography and Geodesy in Frankfurt am Main (former Institute for Applied Geodesy) until just before the earthquake in Izmit on the 17 August 1999. The processing was done using the Bernese 4.0 software from the Astronomical Institute of the University of Bern, and the velocity field was calculated by integrating sessions using the GLOBK software from MIT. In conclusion of the study, the annual displacements in the Sapanca and Düzce regions along the NAFZ were determined as $17-20 \mathrm{~mm} \mathrm{yr}^{-1}$ on average.

The 1999 earthquake in Düzce, on 12 November also effected the east of the Marmara region. In another study conducted by Ayhan et al. (2001a), after this 1999 earthquake in
Düzce identified that the lateral strike slip was $3.76 \mathrm{~m}$, and the maximum lateral strike slip along the surface crack was indicated as $5 \mathrm{~m}$ as a result of a geological assessment.

Another resource that can be mentioned regarding the effects of an earthquake is the temporal point displacements within the stations of the Turkish National Fundamental GPS Network (TUTGA). This network, consisting of about 600 points, was established prior to the earthquakes in Izmit and Düzce in 1999, and has 53 common points with networks established within the context of geodynamic projects underway throughout Turkey. The majority of these points are located in the west and northwest of the country. The first velocity vectors from the TUTGA network were determined using these points, and the strategy of velocity estimation used also applied to determine the velocity of other points included in the IGNA network discussed in this paper.

Second period observations of the stations within the TUTGA network were completed in 2003. The baseline lengths between the stations in this network vary from 25 to $70 \mathrm{~km}$, and most of these points are located in the areas with different tectonical characteristics to focus the current tectonical features of the Anatolian plate. Because a large number of stations covering almost all important tectonic faults in Turkey have been observed during the GPS campaigns, this enabled Ayhan et al. (2002) to develop a realistic tectonic model to describe the movement of Anatolia relative to the main plates in its surroundings and to explain the tectonical characteristics of the areas of the plate boundaries. Figure $3 \mathrm{a}$ and $b$ illustrate the sizes of horizontal and vertical velocity vectors estimated by Ayhan et al. (2001b) using the GPS observations within the TUTGA network.

In addition to the GPS measurements carried out within the TUTGA network after the region's two major 1999 earthquakes, vertical movements of stations were also calculated based on levelling observations. Accordingly, vertical displacements varying between -52.7 and $+28.8 \mathrm{~cm}$ were determined within the earthquake zone between Düzce and Izmit. In the Gölcük region located to the south of the NAFZ, a rising of $20 \mathrm{~cm}$ was detected. Meanwhile, in the northern part of the Izmir Gulf a subsidence of $20 \mathrm{~cm}$ was observed (Cingöz and Demir, 2002).

\section{Istanbul GPS Triangulation Network (IGNA)}

Projects to establish a modern cadastral system and a proper geodetic network in Istanbul date back to 1911. The first modern studies started in the historical peninsula and then developed to date in accordance with the city's development (Güneş et al., 1985). The most recent study to establish a geodetic network in Istanbul was in 1999. The IGNA, a densely geodetic network that incorporates the metropolitan area of the city of Istanbul, was set up in 1999, including about 650 stations to form a geodetic infrastructure for engineering studies. The IGNA network was established by 


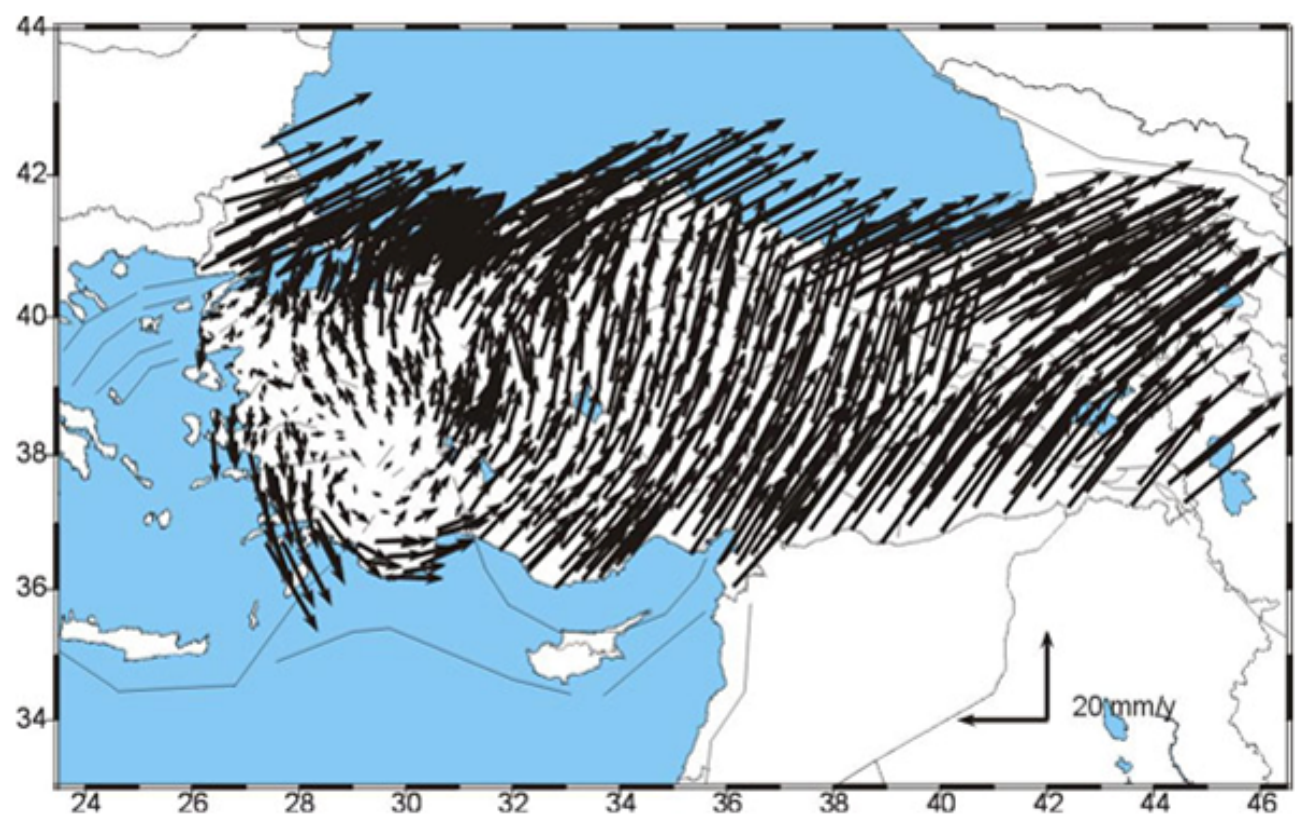

Fig. 3a. Horizontal velocity vectors of the stations within the TUTGA network estimated using GPS observations (Ayhan et al., 2001b).

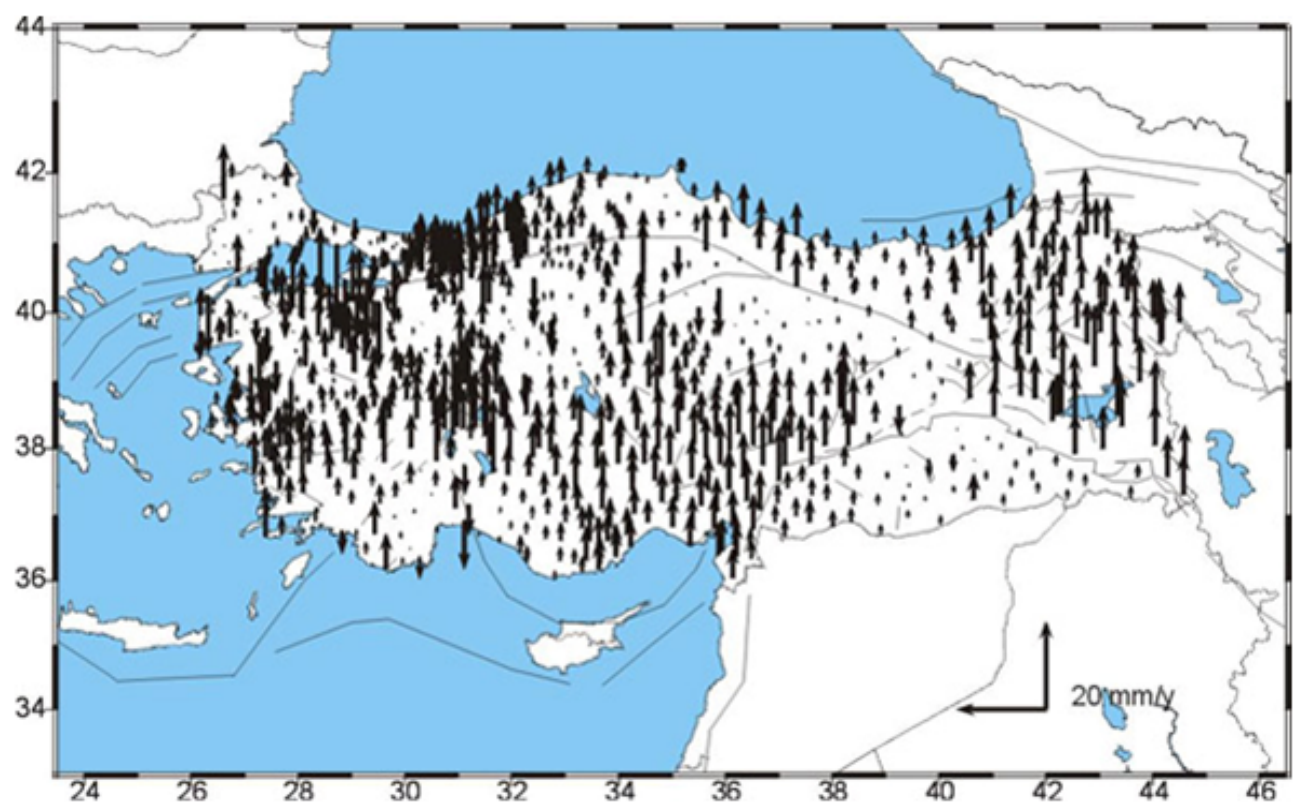

Fig. 3b. Vertical velocity vectors of the stations within the TUTGA network estimated using GPS observations (Ayhan et al., 2001b).

the Istanbul Metropolitan Municipality in such a way that there are points distributed homogeneously for obtaining accurate and reliable coordinate information in the ITRF (International Terrestrial Reference Frame) datum and ED50Datum (European Datum, 1950). The baseline lengths between the stations in the IGNA network are between 15 and $20 \mathrm{~km}$. The relationship of the IGNA with the Turkish National Fundamental Control Network, which was established in the past using terrestrial techniques with the purpose to set up a national surveying network covering all area of Turkey, was realized using common station coordinates within both networks. Before the second GPS campaign conducted in IGNA in 2005, the number of network stations was increased to 1888 (Ayan et al., 2006a, b).

In the processing phase of IGNA in 1999, firstly, the primary network of 58 points was assessed, and then the mean square errors for the longitude and latitude values were determined as $\pm 1 \mathrm{~cm}(\max 1.3 \mathrm{~cm})$, and the mean square errors 


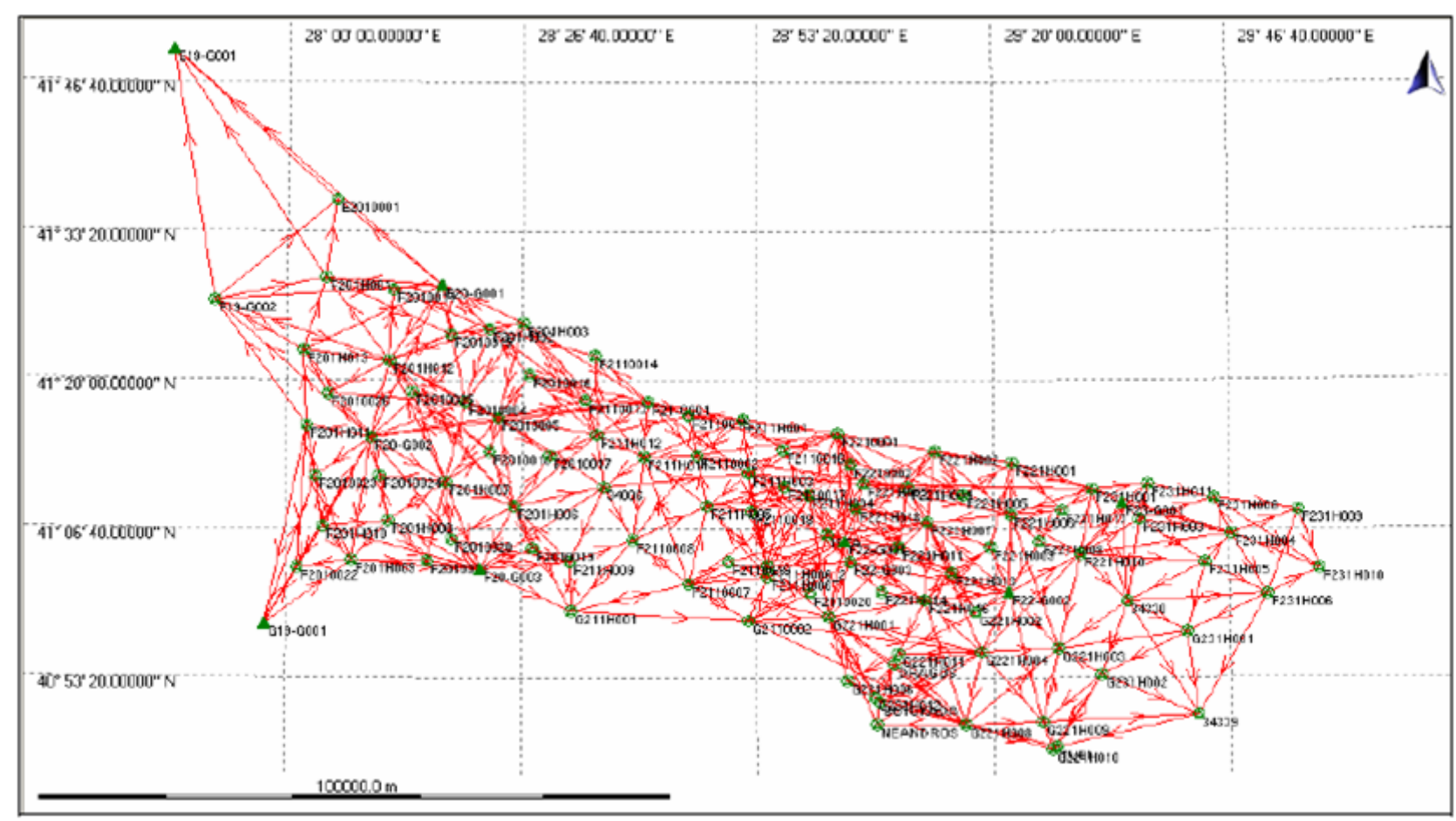

Fig. 4. IGNA Primary GPS Network 2005 (Ayan et al., 2006b).

of average ellipsoidal heights were determined as $\pm 1-2 \mathrm{~cm}$ (max. $2.8 \mathrm{~cm}$ ) after the adjustment computations. The densification network points were calculated based on the primary network points. Total number of fundamental GPS network points plus the number of densification GPS network points was 650 (Ayan et al., 1999). Station coordinates were computed in ITRF94 datum (reference ellipsoid GRS80-Geodetic Reference System, 1980) with the reference epoch of 1998.0.

As pointed out, the number of network points in the 2005 measurement campaign in the IGNA is $1888 ; 107$ primary and 1781 densification points. Included in the established primary network are the ISTA and TUBI points of the International Global Navigation Satellite Systems Service (IGS), as well as BADT, DRAGOS and NEANDROS points, the permanent stations established by TUBITAK (The Scientific and Technological Research Council of Turkey) as part of the Marmara Continuous GPS Network (MAGNET) project. Figure 4 illustrates the primary GPS network of IGNA formed with 107 points. After the network adjustment, the latitude accuracies vary between $\pm 0.2-0.7 \mathrm{~cm}$, the longitude accuracies vary between $\pm 0.1-0.5 \mathrm{~cm}$, and the ellipsoidal height accuracies vary between $\pm 0.4-1.5 \mathrm{~cm}$. In the densification network, the latitude accuracies vary between $\pm 0.2-3.0 \mathrm{~cm}$, the longitude accuracies vary between $\pm 0.2-1.6 \mathrm{~cm}$, and the ellipsoid height accuracies vary between $\pm 0.5-5.0 \mathrm{~cm}$ (Ayan et al., 2006b). Station coordinates were computed in ITRF96 datum with the reference epoch of 2005.0.

In both campaigns, GPS data processing was performed using Bernese 5.0 and Leica Geo Office GPS processing software.

\section{Displacements in the IGNA Network}

Horizontal and vertical displacements of the points in the Primary Network and the Densification Network were determined using the common point coordinates of IGNA1999 and the IGNA-2005 campaigns. The baseline components between stations and their covariance matrices obtained from GPS processing were used for the determination of point displacements. The orbital differences between two campaigns were neglected. For deformation analysis, ANKR, an IGS station located on Anatolian plate at $39.89^{\circ} \mathrm{N}, 32.76^{\circ} \mathrm{E}$, was also included in the network. For the connection of ANKR to the network, the data collected at some primary network points with the longest observation times were used. This was accomplished for both campaigns. Then the network was minimally constrained by fixing the ITRF96, epoch 1998.0, coordinates of ANKR only in order to avoid any datum effects within the internal geometry of the network. For deformation analysis, a conventional similarity-transformation based deformation analysis procedure was applied as described by Acar et al. (2006). 


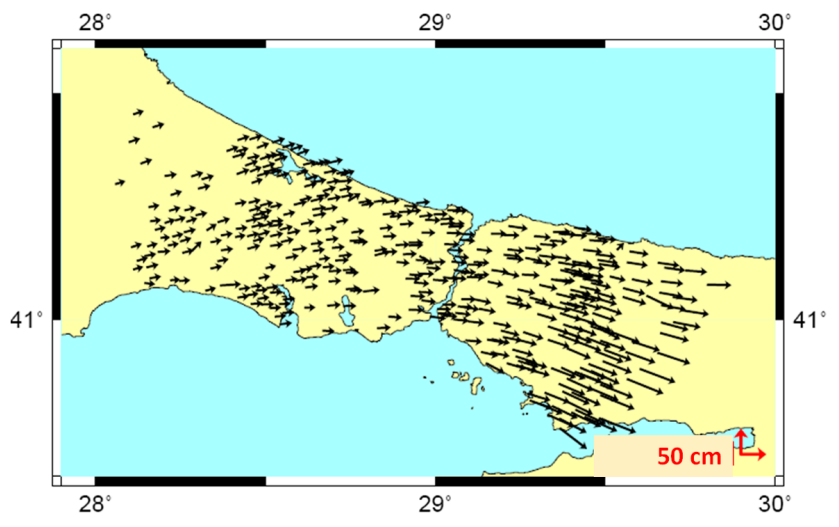

Fig. 5. Horizontal displacements of stations, estimated relative to the ANKR station (created using the GMT software) using GPS observations conducted within the IGNA network in 1999 and 2005.

The movements of stations estimated with a confidence level of 0.95. Magnitudes of surface deformations at control stations were attained when the coordinates obtained from both observation periods in 1999 and 2005 are compared with each other. During the evaluation process, 46 points, 5 of which were from the fundamental network, from a total of 498 points measured within the both GPS campaigns, were excluded during the data processing as outliers because of their uncertainty. As a result, displacements of 452 common points were estimated relative to the ANKR station. Right, upward projection horizontal coordinate differences and differences in ellipsoidal heights were used as input values in the Generic Mapping Tools (GMT) programme.

The largest horizontal displacement among 47 Primary Network points was $74.3 \mathrm{~cm}$, and the smallest was $19.5 \mathrm{~cm}$. The largest vertical displacement was $11.3 \mathrm{~cm}$, and the smallest was $0.03 \mathrm{~cm}$. When the horizontal displacements, obtained using 405 densification points, were taken into consideration, the largest horizontal displacement was $89.6 \mathrm{~cm}$, and the smallest was $18.4 \mathrm{~cm}$. The highest vertical displacement among densification points was $-31.3 \mathrm{~cm}$, and the lowest was $0.05 \mathrm{~cm}$. Figures 5 and 6 illustrate the horizontal and vertical displacements obtained for all network points, respectively (Özyaşar, 2009).

When all network points are considered, the points are moving eastwards within the study area. An increase was observed in the horizontal displacements of the network points in the east, being closer to the epicentre of the earthquakes in East Marmara. An increase was observed in the vertical displacements on the north coastal regions and regional changes at some points displayed differences with their high values, which could have arose due to the local geological processes around these points.

The results obtained from the points in the region where TUBI is located, an IGS station situated to the east of the IGNA network, are in agreement with the results of the study of Ehrensberger (2000), who analysed the movement

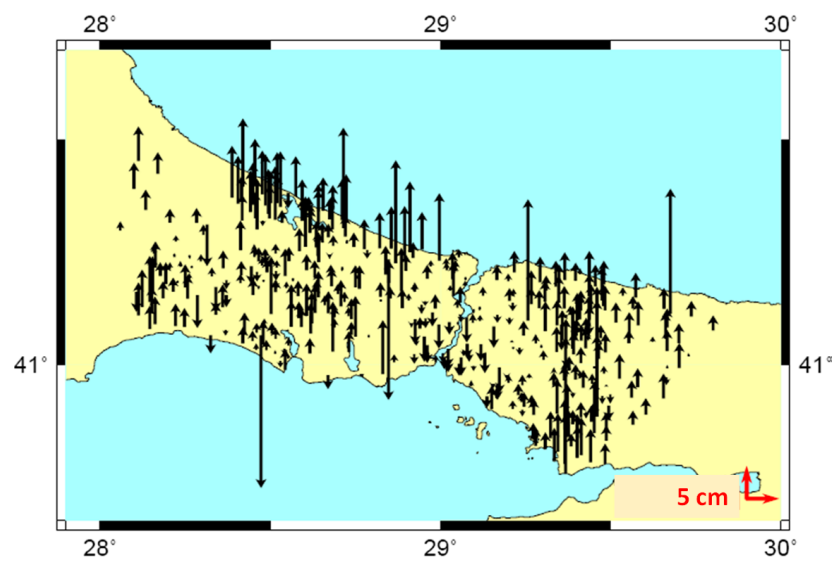

Fig. 6. Vertical displacements of stations, estimated relative to the ANKR station (created using the GMT software) using GPS observations conducted within the IGNA network in 1999 and 2005.

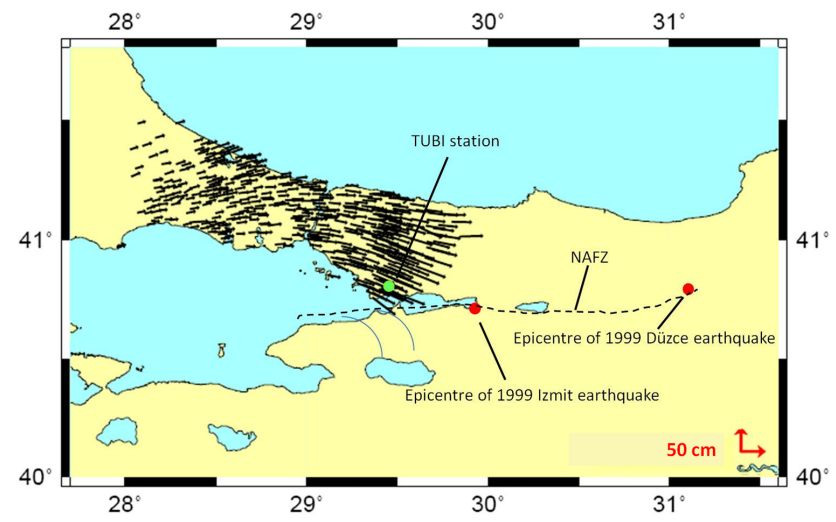

Fig. 7. The horizontal displacement vectors relative to the ANKR station, the epicentres of Izmit and Düzce earthquakes, and locations of TUBI and the NAFZ.

of stations of the EUREF network, including the IGS station TUBI. In another study, Doğan et al. (2003) determined the coseismic displacements of some MAGNET points and TUBI. The amount and direction of TUBI's displacement are also consistent with the results obtained in this study. For a better understanding, the horizontal displacement vectors, the epicentres of Izmit and Düzce earthquakes, and locations of TUBI and the NAFZ are shown in Fig. 7.

\section{Conclusions}

The NAFZ was the subject of numerous scientific studies before and after the earthquakes in East Marmara. These studies were evaluated under the aspect of two separate categories studies carried out by different disciplines and the studies conducted by geodesists focusing on the determination of crustal movements and velocity vectors. 
The IGNA-1999 was designed as a combination of primary network and densification network points, totalling 650 points. After the IGNA project, whose technical report was published in 1999, the earthquake in Izmit occurred on 17 August and the earthquake in Düzce occurred on 12 November. The displacements experienced as a result of these 1999 earthquakes required the IGNA to be re-measured and re-evaluated. As a result of the re-measurement of the IGNA between 2005 and 2006, the number of points tripled. When compared, the horizontal displacements before and after the earthquakes showed a difference that ranges between $+18.4 \mathrm{~cm}$ and $+89.6 \mathrm{~cm}$, while the vertical displacements showed a difference ranging between $+27.9 \mathrm{~cm}$ and $-31.3 \mathrm{~cm}$. The magnitude of the differences experienced may have occurred because the IGNA project was designed as a basis for daily engineering activities and the GPS measurement periods were kept relatively short according to deformation studies based on this design.

When all of the points in the Istanbul GPS Triangulation Network are taken into consideration, an eastward horizontal displacement trend was detected in the study area. An increase in horizontal displacements was observed nearer to the epicentres of the earthquakes in East Marmara. Further, an increase was observed in vertical displacements on the north coastal regions and some points portrayed an unexpected increase due to regional geological processes around these stations.

When horizontal and vertical displacements were assessed together with the ground, it was observed that ground properties alone did not affect displacements, and an increase was observed in the difference of horizontal displacements in the east region, nearer to the epicentre of the earthquakes experienced in East Marmara, in comparison to the west region of Istanbul where the ground is more loose. The difference in vertical displacements portrayed different behaviours according to the soil, excluding the block movement. It is possible to say that vertical displacements generally occur during earthquakes. In addition, the majority of moderate and intense earthquakes increase the liquefaction of ground, trigger mass movements such as rock falls, and cause different earth movements within the same region.

Lateral strike slip earthquakes that register below 6 on the Richter Scale do not create movement over the sensitivity of geodetic measurements. Turkey, located in the region where the tectonic plates of Arabia and Africa collide with the tectonic plate of Eurasia, has experienced numerous earthquakes that register above 6 on the Richter Scale. However, it is possible to state that horizontal and vertical crustal movements have occurred throughout the years at a magnitude well over the sensitivity of geodetic measurements, regardless of earthquakes occurring. The results obtained for the horizontal and vertical displacements using the measurements carried out during both periods on the points of the IGNA reflect the general characteristics of the NAFZ.
The results are also consistent with the past studies conducted in the same region.

The fact that the majority of Turkey is within a seismic zone makes collaborative working of numerous disciplines inevitable when carrying out studies after earthquakes, and when carrying out studies to predetermine earthquakes. The aim of geodetic studies carried out in regions prone to earthquakes is to determine crustal stresses and small crustal movements that cause earthquakes or to determine the location, direction, and magnitude of the displacements that arise during and after an earthquake. Present geodetic networks enable geodetic studies to fulfil the aforementioned objective. In fact, these geodetic networks are commonly used in engineering measurements carried out as part of daily engineering activities. When projects including engineering measurements such as the IGNA example are carried out, they should be designed in a way that considers their contribution towards tectonics, which will then contribute immensely to the studies carried out in this field.

IGNA measurements were conducted in a campaign-style mode, i.e. short measurement surveys separated by long time periods. Campaign based GPS surveys give no indication of the rate of ground movement between the campaigns. Another issue is the stability of station monuments. The obtained results could be contaminated by several factors such as soil movement, centring errors of a tripod, etc. In addition planning and executing GPS campaigns could be quite expensive Moreover logistics problems may occur. A solution to overcome such disadvantages is to adopt a continuous GPS deformation monitoring approach. The setting-up of a continuous GPS infrastructure provides uninterrupted measurements of the displacements in any kind of deformation monitoring.

Continuously operating reference stations could also be a powerful means for deformation monitoring. Today there are nationwide networks of such stations. Such a network has also been established in Turkey: the Continuously Operating Reference Stations Network of Turkey (CORS-TR) became active in 2008. This network consists of 147 stations covering Turkey and the northern part of Cyprus. In fact, the basic objective of the CORS-TR project is to provide reliable positioning for daily engineering activities. Because of the visibility and logistic conditions, many of the stations in urban areas were established on the roofs of the buildings. Although such disadvantages exist, the point locations were chosen in proper places considering the contribution of CORS-TR data to the earthquake related studies. The project is considered to make a valuable contribution to the realization of highly accurate real-time monitoring system of plate tectonics in Turkey, thus enabling continuous measurements of deformation magnitudes and directions (Ylldırım et al., 2003). It is clear that CORS-TR data will be widely used in the future by earthquake researchers. 
Acknowledgements. The authors would like to thank to the members of former Geodesy Division of Istanbul Technical Universitys Geomatics Engineering Department for their great effort in the establishment process of IGNA network.

Edited by: M. E. Contadakis

Reviewed by: S. Leinen and Y. Altiner

\section{References}

Acar, M., Özlüdemir, M. T., Akyilmaz, O., Çelik, R. N., and Ayan, T.: Deformation analysis with Total Least Squares, Nat. Hazards Earth Syst. Sci., 6, 663-669, doi:10.5194/nhess-6-6632006, 2006.

Alpar, B. and Yaltırak, C.: Kuzey Anadolu Fayı'nın Ízmit Körfezi Íçindeki Özellikleri ve 17 Ağustos 1999 Depreminin Etkileri, in: Aktif Tektonik Araştırma Grubu 3. Toplantı Makaleler Kitapçı̆̆ı, Cumhuriyet Üniversitesi, Sivas, 4-5 November 1999, 12-19, 1999 (in Turkish).

Altıner, Y.: Geometrische Modellierung innerer und äusserer Deformation der Erdoberfläche, $\mathrm{PhD}$ Thesis, Bonn University, Bonn, Germany, DGK Reihe C 462, 1996 (in German).

Ayan, T., Aksoy, A., Deniz, R., Arslan, E., Çelik, R. N., Özşamlı, C., Denli, H. H., Erol, S., and Özöner, B.: Ístanbul GPS Nirengi Ağ1 (ÍGNA) -Teknik Rapor, ÍTÜ Ínşaat Fakültesi Jeodezi Anabilim Dalı, 1999 (in Turkish).

Ayan, T., Özlüdemir, M. T., Akyılmaz, O., Arslan, E., and Denli, H. H.: Geodetic network densification in Istanbul-IGNA, in: Proceedings of Fourth International Symposium Turkish-German Joint Geodetic Days, Berlin, Germany, 3-6 April 2001, 515-520, 2001

Ayan, T., Deniz, R., Arslan, E.., Çelik, R. N., Denli, H. H., Özşamlı, C., Özlüdemir, M. T., Erol, S., Akyılmaz, O., Acar, M., Mercan, H., and Tekdal, E.: Remeasurement of Istanbul GPS Network, in: Proceedings of Fifth Turkish-German Joint Geodetic Days, Berlin, Germany, 28-31 March 2006, 2006a.

Ayan, T., Deniz, R., Arslan, E., Çelik, R. N., Denli, H. H., Özşamlı, C., Özlüdemir, M. T., Erol, S., Akyılmaz, O., Acar, M., Mercan, H., and Tekdal, E.: Ístanbul GPS Nirengi Ağ1 2005-2006 Yenileme Ölçü ve Değerlendirmesi (ÍGNA 2005)-Teknik Rapor, ÍTÜ Ínşşaat Fakültesi Jeodezi Anabilim Dalı, 2006b (in Turkish).

Ayhan, M. E., Bürgmann, S., McClusky, S., Lenk, O., Aktuğ, B., Herece, E., and Reilinger, R. E.: Kinematics of the $M_{w}=7.2$, November 1999, Geophys. Res. Lett., 28, 367-370, 2001a.

Ayhan, M. E., Lenk, O., Demir, C., Kılıçoğlu, A., Kahveci, M., Türkezer, A., Ocak, M., Açıkgöz, M., Yıldırım, A., Aktuğ, B., Şengün, Y. S., Cingöz, A., Kurt, A., and Fırat, O.: Türkiye Ulusal Temel GPS Ağı-1999 (TUTGA-99) Teknik Raporu, Harita Genel Komutanlığı Jeodezi Dairesi, Ankara, Şubat 2001, 2001b (in Turkish).

Ayhan, M. E., Demir, C., Lenk, O., Kılıçoğlu, A., Açıkgöz, M., Fırat, O., Şengün, Y. S., Cingöz, A., and Kurt, A.: Türkiye Ulusal Temel GPS Ağı 1999A Teknik Raporu, Harita Dergisi Özel Sayı 16, 2002 (in Turkish).
Barka, A.: The August 17 and November 121999 Earthquakes in the Eastern Marmara Sea Region, in: Proceedings of International Conference on the Kocaeli Earthquake, ITU, Istanbul, Turkey, 2-5 December 1999, 1999.

Cerit, O., Sezen, T. F., and Nurlu, M.: 17 Ağustos 1999 Güney Marmara Depremi Tektonik Özellikleri, in: Aktif Tektonik Araştırma Grubu 3. Toplantı Makaleler Kitapçığı, Cumhuriyet Üniversitesi, Sivas, 4-5 November 1999, 1-11, 1999 (in Turkish).

Cingöz, A. and Demir, C.: 17 Ağustos 1999 Ízmit Depremine Ílişkin Deformasyon Parametrelerinin Kestirimi, in: TUJK 2002 Yılı Bilimsel Toplantısı Tektonik ve Jeodezik Ağlar Çalıştayı Bildiriler Kitabı, Íznik, 10-12 October 2002, 167-182, 2002 (in Turkish).

Doğan, U., Ergintav, S., Demirel, H., Çakmak, R., and Özener, H.: Estimation of the Time-Dependent Crustal Movements of the Izmit Earthquake, J. Geodynamics, 36, 615-632, 2003.

Ehrnsperger, W.: Analysis of the EUREF-Stations in the South-East of Europe with respect to the Izmit Earthquake on August 1999 , in: Report on the Symposium of the IAG Subcommission for Europe (EUREF), Tromso, 22-24 June 2000, 9, 79-88, 2000.

Güneş, Í. H., Ayan, T., and Algül, E.: Ístanbul Nirengi Ağı Üzerine, Íller Bankası Dergisi, Nisan-Mayıs-Haziran, 61-65, 1985 (in Turkish).

Ketin, Í.: Kuzey Anadolu Fayı hakkında, MTA Dergisi, 72, 1-27, 1969 (in Turkish).

Koçyiğit, A.: Marmara Bölgesinin Depremselliği ve Deprem Kaynakları (Faylar), in: 59. Türkiye Jeoloji Kurultayı, Ankara, Turkey, 20-24 March 2006, 5-6, 2006 (in Turkish).

Kutoğlu, H. S., Celik, R. N., Ozludemir, M. T., and Güney, C.: New findings on the effects of the Izmit $M_{\mathrm{W}}=7.4$ and Düzce $M_{\mathrm{W}}=7.2$ earthquakes, Nat. Hazards Earth Syst. Sci., 11, 267272, doi:10.5194/nhess-11-267-2011, 2011.

McClusky, S., Balassanian, S., Barka, A., Demir, C., Ergintav, S., Georgiev, I., Gurkan, O., Hamburger, M., Hurst, K., Kahle, H., Kastens, K., Kekelidze, G., King, R., Kotzev, V., Lenk, O., Mahmoud, S., Mishin, A., Nadariya, M., Ouzounis, A., Paradissis, D., Peter, Y., Prilepin, M., Reilinger, R., Sanli, I., Seeger, H., Tealeb, A., Toksoz, M. N., and Veis, G.: Global Positioning System constraints on plate kinematics and dynamics in the eastern Mediterranean and Caucasus, J. Geophys Res.-Sol. Ea., 105, 5695-5719, 2000.

McKenzie, D. P.: Active tectonics of the Mediterranean region, Geophys J. Roy Astr. S., 30, 109-185, 1972.

Özyaşar, M.: Ístanbul GPS Nirengi Ağ1 1999 ve 2005 Kampanyalarından Yararlanarak Ístanbul Metropoliten Alanında Deprem Sonrasi Hareketlerin Belirlenmesi, MSc Thesis, Istanbul Technical University, Istanbul, Turkey, 2009 (in Turkish).

Reilinger, R., Ergintav, S., and Burgmann, R.: Coseismic and postseismic fault slip for the 17 August 1999, M=7.5, Izmit, Turkey, Science, 289, 1519-1524, 2000.

Şengör, A. M. C.: The North Anatolian Fault; its age, offset and tectonic significance, J. Geol. Soc., 136, 269-282, 1979.

Yıldırım, Ö., Bakıcı, S., Cingöz, A., Erkan, Y., Gülal, E., and Dindar, A. A.: TUSAGA-Aktif (CORS TR) projesi ve ülkemize katkıları, in: TMMOB Harita ve Kadastro Mühendisleri Odası Ulusal Coğrafi Bilgi Sistemleri Kongresi Bildiriler CD'si, Trabzon, 30 October-2 November 2007, 2007 (in Turkish). 